Check for updates

Cite this: Food Funct., 2021, 12, 14

\title{
Phenolic compounds: current industrial applications, limitations and future challenges
}

\author{
Bianca R. Albuquerque, (iD a,b Sandrina A. Heleno, (D)*a M. Beatriz P. P. Oliveira, (ID b \\ Lillian Barros (iD *a and Isabel C. F. R. Ferreira (iD ${ }^{a}$
}

\begin{abstract}
Phenolic compounds are natural bioactive molecules found mainly in plant tissues that have shown interesting bioactivities, such as antioxidant, antimicrobial, anti-inflammatory, and antiproliferative activities, among others, which has led to great interest in their use by several industries. However, despite the large number of scientific studies on this topic, some issues still need to be studied and solved, such as the understanding of the main actions of these compounds in organisms. Besides their large potential applicability in industry, phenolic compounds still face some issues making it necessary to develop strategies to improve bioavailability, sustainable technologies of extraction and refinement, and stability procedures to increase the range of applicability. This review focuses on the most recent advances in the applications of phenolic compounds in different technological and medicinal areas. In addition, techniques to improve their sustainable resourcing, stability and bioavailability will be presented and discussed.
\end{abstract}

Received 2nd September 2020, Accepted 4th November 2020

DOI: $10.1039 /$ dOfo02324h

rsc.li/food-function information since several factors, such as bioavailability and absorption of these compounds, can interfere with their bioactive action. ${ }^{1,4}$

In addition to the pharmacological interest in these compounds, their biological activities have also been explored in other industry sectors, such as in the food, ${ }^{1,5,6}$ in the $\operatorname{cosmetic}^{3,7}$ and in the packaging and textile industries. ${ }^{8,9}$

This review presents a detailed description regarding the applications and limitations of PC in industry, aiming to create a future perspective for studies and practical use of these compounds. generation of free radicals that attack the cells, leading to serious diseases, such as cancer, cardiovascular diseases, atherosclerosis, neurological disorders, hypertension, and diabetes mellitus, due to oxidative and nitrosative stress. ${ }^{1,2}$ Other important bioactivities for maintaining good health have also been associated with these compounds, e.g. anti-inflammatory, antimicrobial, and anti-proliferative activities $;^{1-3}$ these biological activities have aroused interest in the use of these molecules in the formulation of nutraceutical products. ${ }^{1,2}$ However, although many bioactivities of PC are proven in vitro, there is still a lack of information on their action in vivo; this is crucial

\footnotetext{
${ }^{a}$ Centro de Investigação de Montanha (CIMO), Instituto Politécnico de Bragança, Campus de Santa Apolónia, 5300-253 Bragança, Portugal. E-mail: lillian@ipb.pt, sheleno@ipb.pt; Tel: +351-273-303285,+351-273-303285

${ }^{b}$ REQUIMTE - Science Chemical Department, Faculty of Pharmacy, University of Porto, Rua Jorge Viterbo Ferreira no. 228, 4050-313 Porto, Portugal
}

\section{Phenolic compounds}

PC are the main substances formed by the secondary metabolism of plants. They are responsible for pigmentation and astringency and also act as protective agents against UV light, besides protecting the plants against parasites and insects. ${ }^{1,2}$ These compounds can be found in a huge diversity of matrices, such as fruits and vegetables, among others (Table 1).

Another important approach is obtaining PC from residues and byproducts of the food production chain, since it is a cheap natural source of these compounds, and has no economic value, contributing to the reduction of waste, because agri-food bioresidues represent a significant percentage in the food processing industries. For example, wine making residues correspond to $20 \%-30 \%(\mathrm{w} / \mathrm{w})$ of the total processed grapes 
Table 1 Bioactive properties of the phenolic compounds

\begin{tabular}{|c|c|c|c|}
\hline Phenolic compound & Main sources & Bioactivities & Ref. \\
\hline \multicolumn{4}{|l|}{ Phenolic acids } \\
\hline \multicolumn{4}{|l|}{ Hydroxybenzoic acids } \\
\hline Sinapic acid & $\begin{array}{l}\text { Berries, rye, mustard and } \\
\text { vegetables }\end{array}$ & $\begin{array}{l}\text { Antioxidant, anti-inflammatory, antimicrobial, and } \\
\text { anticancer activities. }\end{array}$ & 69 \\
\hline Ellagic acid & Berries & Antioxidant, anti-inflammatory, and antitumoral activities. & 2 \\
\hline Gallic acid & Grapes, tea and wine & $\begin{array}{l}\text { Antioxidant, antimicrobial, anti-inflammatory, } \\
\text { antitumoral, and neuroprotective activities. }\end{array}$ & $\begin{array}{l}12 \text { and } \\
37\end{array}$ \\
\hline \multicolumn{4}{|l|}{ Hydroxycinnamic acids } \\
\hline Ferulic acid & $\begin{array}{l}\text { Cereal grains, fruits, } \\
\text { mushrooms and rice }\end{array}$ & $\begin{array}{l}\text { Antioxidant, antitumoral, antimicrobial, and antidiabetic } \\
\text { activities. }\end{array}$ & 12 \\
\hline Caffeic acid & $\begin{array}{l}\text { Coffee, mushrooms and } \\
\text { propolis }\end{array}$ & $\begin{array}{l}\text { Antioxidant, antimicrobial, anti-inflammatory, antiviral, } \\
\text { and antitumoral activities. }\end{array}$ & 12 \\
\hline$p$-Coumaric acid & $\begin{array}{l}\text { Carrot, coffee, garlic, grapes, } \\
\text { spinach and tomatoes }\end{array}$ & $\begin{array}{l}\text { Antioxidant, antimicrobial, antiviral, antitumoral, anti- } \\
\text { inflammatory and neuroprotective activities. }\end{array}$ & $\begin{array}{l}12 \text { and } \\
15\end{array}$ \\
\hline \multicolumn{4}{|c|}{ 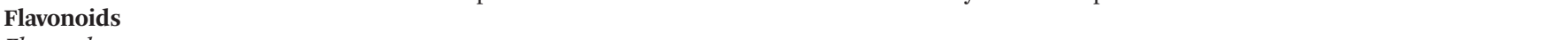 } \\
\hline \multicolumn{4}{|l|}{ Flavonols } \\
\hline Kaempferol & $\begin{array}{l}\text { Cabbage, cauliflower, propolis } \\
\text { and spinach }\end{array}$ & $\begin{array}{l}\text { Antioxidant, anti-inflammatory, antitumoral, and } \\
\text { cardioprotective activities. }\end{array}$ & 2 \\
\hline Myricetin and derivatives & Berries, herbs and vegetables & Antioxidant, anti-inflammatory, and antitumoral activities. & 70 \\
\hline Quercetin and derivatives & $\begin{array}{l}\text { Apples, berries, onion and } \\
\text { pears }\end{array}$ & $\begin{array}{l}\text { Antioxidant, anti-inflammatory, antitumoral, and } \\
\text { cardioprotective activities. }\end{array}$ & 2 \\
\hline \multicolumn{4}{|c|}{${ }^{1}$} \\
\hline Apigenin & Fruits and vegetables & $\begin{array}{l}\text { Antioxidant, anti-inflammatory, antiviral, antiproliferative, } \\
\text { and antitumoral activities. }\end{array}$ & 2 \\
\hline Tangeretin & Citrus fruits & $\begin{array}{l}\text { Anti-inflammatory, antiproliferative, and antitumoral } \\
\text { activities. }\end{array}$ & 71 \\
\hline Baicalein & Scutellaria Baicalensis Georg & $\begin{array}{l}\text { Antioxidant, anti-inflammatory, and neuroprotective } \\
\text { activities. }\end{array}$ & $\begin{array}{l}72 \text { and } \\
73\end{array}$ \\
\hline Luteolin & $\begin{array}{l}\text { Broccoli, celery and green } \\
\text { peppers }\end{array}$ & Antioxidant, anti-inflammatory, and antitumoral activities. & $\begin{array}{l}2 \text { and } \\
25\end{array}$ \\
\hline \multicolumn{4}{|l|}{ Flavanols } \\
\hline Catechin & Berries, cacao and green tea & Antioxidant and antimicrobial activities. & 2 \\
\hline $\begin{array}{l}\text { Epicatechin gallate, epigallocatechin, } \\
\text { and epigallocatechin gallate }\end{array}$ & $\begin{array}{l}\text { Berries, cacao, grapes and } \\
\text { green tea }\end{array}$ & $\begin{array}{l}\text { Anti-inflammatory, anti-obesity, and cardioprotective } \\
\text { activities. }\end{array}$ & 2 \\
\hline \multicolumn{4}{|l|}{ Flavanones } \\
\hline Hesperidin & Citrus fruits & $\begin{array}{l}\text { Antioxidant, anti-inflammatory, antitumoral, and } \\
\text { antiallergic activities. }\end{array}$ & $\begin{array}{l}1 \text { and } \\
74\end{array}$ \\
\hline Naringin & Citrus fruits and grapefruit & $\begin{array}{l}\text { Antioxidant, anti-inflammatory, anticancer, anti-lipidemic, } \\
\text { and antibacterial activities. }\end{array}$ & $\begin{array}{l}2 \text { and } \\
24\end{array}$ \\
\hline Taxifolin & $\begin{array}{l}\text { Bark (genus Pinus or Larix) } \\
\text { and seeds (genus Silybum) }\end{array}$ & $\begin{array}{l}\text { Antioxidant, anti-inflammatory, antiviral, and antibacterial } \\
\text { activities, and anticancer, neuroprotective activities. }\end{array}$ & 75 \\
\hline Isoflavones & Soybeans and soyproducts & Cardioprotective activity, estrogenic effects. & 2 \\
\hline Anthocyanins & $\begin{array}{l}\text { Berries, grapes and purple } \\
\text { carrot }\end{array}$ & $\begin{array}{l}\text { Antimicrobial, anti-inflammatory, antioxidant, anti- } \\
\text { proliferative, and cardioprotective activities. }\end{array}$ & 2 \\
\hline \multicolumn{4}{|l|}{ Tannins } \\
\hline $\begin{array}{l}\text { Epigallocatechin gallate } \\
\text { Gallotannin }\end{array}$ & Apples, berries and cacao & Antioxidant, antimicrobial, and antitumoral activities. & 1 \\
\hline \multicolumn{4}{|l|}{ Stilbenes } \\
\hline Resveratrol & Berries, grapes and peanuts & $\begin{array}{l}\text { Antioxidant, anti-inflammatory, and cardioprotective } \\
\text { activities. }\end{array}$ & 2 \\
\hline Lignans & Flaxseed and sesame & $\begin{array}{l}\text { Antioxidant, anticancer, anti-inflammatory, } \\
\text { neuroprotective, and antimicrobial activities. }\end{array}$ & $\begin{array}{l}2 \text { and } \\
6\end{array}$ \\
\hline
\end{tabular}

and around $70 \%$ of grape polyphenols remain in the pomace. ${ }^{3}$ Other examples are pomegranate (Punica granatum L.) peels rich in PC, which correspond to up to $40 \%$ of the whole fruit; however they are usually considered as waste; ${ }^{10}$ and anthocyanins can also be obtained from pomace and peel discarded from juice, jam and wine production. ${ }^{3,11}$

In terms of chemical features, $\mathrm{PC}$ are formed by one or more aromatic rings bonded to one or more hydroxyl groups, ${ }^{2,6}$ resulting in different chemical structures; these compounds are divided into different groups: phenolic acids, flavonoids, tannins, stilbenes and lignans. ${ }^{1,4}$

\subsection{Phenolic acids}

Phenolic acids represent the simplest class of PC; their basic structure contains one phenolic ring and a carboxylic acid function, and, according to their carbon skeleton, they are divided into two groups: (i) hydroxybenzoic acids (C6-C1) that are derived from benzoic acid and (ii) hydroxycinnamic acids (C6-C3) that are derived from cinnamic acid (Fig. 1A.1). ${ }^{2,12}$ The last one is composed of the most common phenolic acids, such as caffeic and ferulic acids, ${ }^{2,12}$ found in vegetables, fruits and grains as presented in Table 1. In general, these compounds have several important bioactivities (Table 1). 


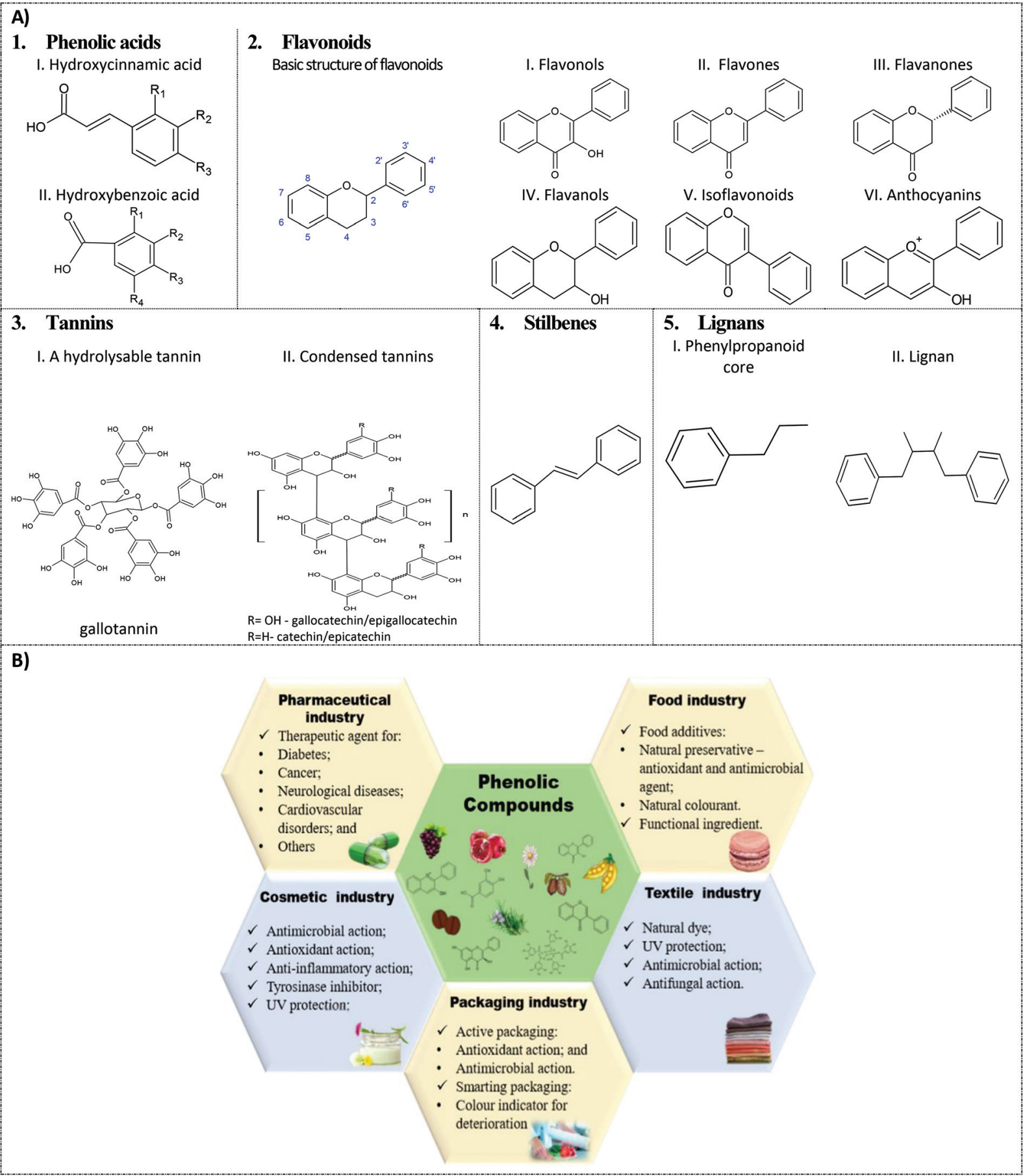

Fig. 1 Main phenolic compounds and their industrial application. (A) Chemical structures. (B) Industrial applications.

\subsection{Flavonoids}

Flavonoids are the most abundant PC, with more than 8000 compounds. Their basic structure consists of fifteen carbon atoms (C6-C3-C6), which are built in two benzene rings (A and B), linked by a heterocyclic pyrane ring (C) (Fig. 1A.2). According to the bond between $\mathrm{B}$ and $\mathrm{C}$ rings and the substitution patterns of the $\mathrm{C}$ ring, they are divided into six different sub-groups: flavonols, flavones, flavonones, flavanols, isoflavonoids and anthocyanins. ${ }^{2,6}$ This class of compounds is widespread in several food matrices and is highly investigated for their diverse bioactivities (Table 1). Regarding their antioxidant capacity, the configuration, substitution and the number of hydroxyl groups are substantially responsible for giving this bioactivity to these compounds. ${ }^{2,6}$ 
2.2.1 Flavonols. Flavonols are flavonoids with a double bond between $\mathrm{C} 2$ and $\mathrm{C} 3$, with a hydroxyl group attached at the $\mathrm{C} 3$ and a carboxyl group at C4 (Fig. 1A.2I); this configuration has three functional groups available to exercise their reaction with other substances. ${ }^{2,6}$ These flavonoids are found in many edible and medicinal plants, being highly investigated due to their multiple bioactivities (Table 1). Among this group, the most known compounds are kaempferol, myricetin, quercetin and their respective derivatives of quercetin. ${ }^{2}$

2.2.2 Flavones. Flavones have a double bond between $\mathrm{C} 2$ and $\mathrm{C} 3$, with a structure similar to flavonols, but with the absence of a hydroxyl group at C3 (Fig. 1A.2II). Some flavones and their respective sources and bioactivities can be found in Table 1. Luteolin and apigenin are the most abundant flavones; the presence of free hydroxyl groups in their rings A and $\mathrm{B}$ is responsible for their antioxidant activity. ${ }^{2,6}$

2.2.3 Flavanones. There are more than 160 types of flavanones belonging to 36 plant families, being also precursors of many other flavonoids. ${ }^{2,6}$ These compounds are chemically characterized by containing a carboxyl group at position 4 , without the presence of a double bond between C2 and C3 (Fig. 1A.2III). ${ }^{2}$ Flavanones are mainly found in citrus fruits (Table 1). Among this class of compounds, naringenin and hesperidin are the most investigated. ${ }^{2,6}$

2.2.4 Flavanols. Flavanols, also known as flavan-3-ols, are the largest sub-group of flavonoids. This class is characterized only by the presence of a functional hydroxyl group at position 3 (Fig. 1A.2IV). ${ }^{2,6}$ The major compounds of this class are catechin and epicatechins. ${ }^{2}$ Flavan-3-ols can be found in several fruits and plants (Table 1). Among these sources, green tea (Camellia sinensis L.) stands out for the high concentration of these compounds in its composition, and, due to the bioactivities of flavan-3-ols, the ingestion of this tea has been associated with low incidence of chronic cardiovascular disease. ${ }^{1,2}$

2.2.5 Isoflavonoids. Isoflavonoids are the only flavonoids that have the benzenoid substituent at position 3 (Fig. 1A.2V), which gives them a structure similar to endogenous estrogens, making them capable of displaying agonistic and anti-agonistic interactions with estrogen receptors. ${ }^{2,6}$ More than 2000 isoflavonoids have been identified, of which isoflavones are the most known; ${ }^{2}$ this compound shows interesting bioactivities (Table 1).

2.2.6 Anthocyanins. Anthocyanins are derived from flavonols that have a hydroxyl group at position 3. In addition they have two double bonds (one between the oxygen atom and carbon and the other one between carbon 3 and 4), and there is a lack of a ketone oxygen at position 4 (Fig. 1A.2VI); therefore its structure is basically described as being a flavylium ion. ${ }^{2,6}$ Anthocyanins are responsible for the colour of several red-purple fruits, vegetables and flowers. Aglycone anthocyanins are denoted as anthocyanidins; in nature there are 17 natural anthocyanidins, and cyanidin, delphinidin, petunidin, peonidin, pelargonidin and malvidin are the most common species. ${ }^{5}$ In Table 1 are presented the main sources and bioactivities of these PC. In addition to their interesting health ben- eficial bioactivities, anthocyanins have been used as natural colourants, especially by the food industry. ${ }^{1,5}$

\subsection{Tannins}

Tannins are the major phenolic polymers found in plant tissues. These molecules are known to confer astringent and bitter taste to some fruits (e.g. in Table 1). Tannins are complex phenolics that are divided into two subclasses: hydrolysable tannins and condensed tannins. Hydrolysable tannins are blends of simple phenols, e.g. ellagic and gallic acids, with a carbohydrate. When subjected to acid or basic conditions, these compounds can be hydrolysed producing phenolic acids and carbohydrate molecules; an example is a hydrolysed tannin structure formed from gallic acid (gallotannin) ${ }^{2}$ (Fig. 1A.3I). Condensed tannins are formed by condensing two or more monomers of flavan-3-ol units, linked together mostly by bonds between the A rings of the flavanol units and the pyran rings of other flavanols ${ }^{2}$ (Fig. 1A.3II). Regarding bioactive potential, tannins are little investigated, probably due to the complexity of their structure; however, in the last few years, proanthocyanidins have attracted attention due to their health benefits. $^{2}$

\subsection{Stilbenes}

Stilbenes are characterized by the chemical structure C6C2-C6, with two benzene rings connected by a double bond (Fig. 1A.4). ${ }^{2,6}$ According to the central double bond, they are divided into the isomers $Z$ and $E$; changing the isomerization type generally decreases its biological activity. ${ }^{2}$ There are more than 400 stilbenes known; however, the presence of these substances is limited to plant families that have the key enzyme involved in stilbene biosynthesis. ${ }^{1}$ Resveratrol is one of the most known stilbenes; and due to its bioactivities (Table 1), this compound has been widely studied. $^{2,6}$

\subsection{Lignans}

Lignans are secondary plant metabolites exhibiting different chemical structures; however, the basic structure is composed of the combination of phenylpropanoid dimers (C6-C3, Fig. 1A.5I) linked by the central carbons of the side chains (Fig. 1A.5II). ${ }^{2}$ This class of PC is present in some seeds (Table 1). Lignans have estrogenic and anti-estrogenic activities, ${ }^{1}$ in addition to other bioactivities (Table 1 ).

\section{Phenolic compounds as potential pharmaceutical agents}

PC are bioactive compounds that are normally associated with protective action for maintaining good health when consumed in the regular diet. These compounds have showed inhibitory action against the evolution of several serious diseases, such as cancer, Alzheimer's, and diabetes, among others. ${ }^{1,2}$ These beneficial effects have been attributed mainly to the antioxidant and radical scavenging activities that can delay or 
Table 2 Phenolic compounds used for treatment and prevention of diseases

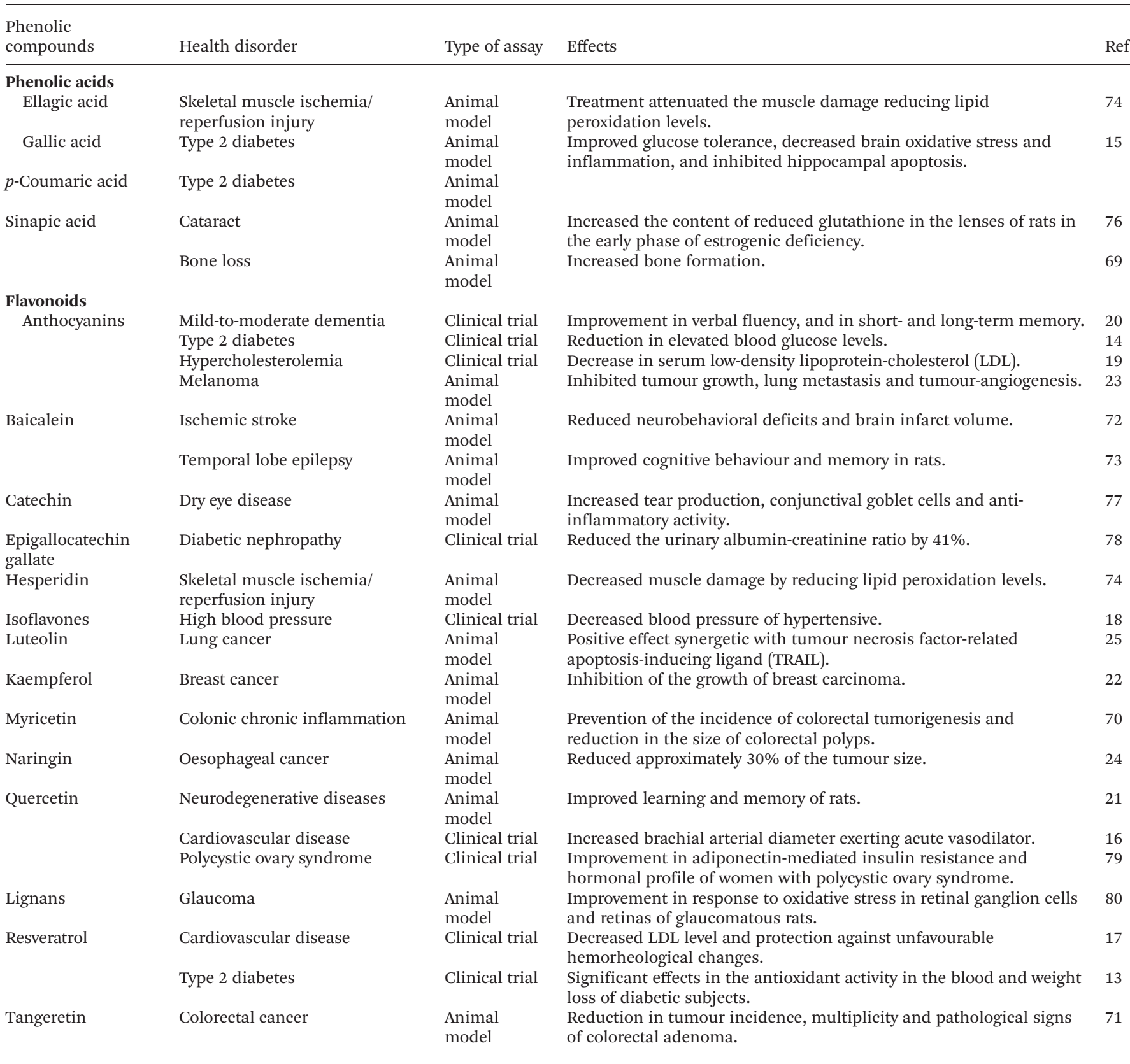

inhibit the oxidation of DNA, proteins and lipids. ${ }^{1,2,6}$ This review introduces some scientific studies (Table 2) that prove the efficacy of PC as pharmaceutical agents in alternative or in synergism with aggressive treatments of diverse ailments.

Diabetes, for instance, is a chronic disease that affects a significant portion of population; the number of diabetic patients has been growing year by year. In 2030 , it is estimated that at least 400 million of people will be diagnosed with diabetes disorder. Oxidative stress has been indicated as a precursor of diabetes disorder; in fact, the reactive oxygen species (ROS) that are not neutralized lead to inflammatory conditions in the body; thus, the antioxidant action of PC has been studied in the treatment of diabetes. ${ }^{2,13-15}$ Anthocyanins have showed an inhibitory action against the $\alpha$-amylase and $\alpha$-glucosidase enzymes, which leads to a reduction in the hydrolysis of carbohydrates in monosaccharides, thus hindering their absorption. ${ }^{14}$ In diabetic mice, supplementation with anthocyaninrich lowbush blueberry extract (500 $\mathrm{mg}$ per wb) or with malvidin-3-O-glycoside (300 $\mathrm{mg}$ per wb) showed high reduction in blood glucose levels compared with the known anti-diabetic drug, metformin $\left(27 \%, 300 \mathrm{mg}\right.$ per wb). ${ }^{14}$ In diabetic subjects, the daily consumption of resveratrol $\left(800 \mathrm{mg}\right.$ day $\left.^{-1}\right)$ has been sufficient to increase the antioxidant capacity of the blood, in addition to contributing positively to other health parameters, such as the decrease in blood pressure, weight and body mass index (BMI) of the patients. ${ }^{13}$ 
Cardiovascular diseases (CVD) are highly associated with dietary habits; thus, a diet based on fruits, cereals and vegetables is recommended to prevent CVD. ${ }^{2}$ Some PC have showed cardioprotective action due to their bioactive properties, namely being a potential vasodilator, with antiplatelets and ability to reduce blood pressure and LDL-cholesterol. ${ }^{2,16-19}$ For instance, the treatment with resveratrol $\left(10 \mathrm{mg}\right.$ day $^{-1}$ for 3 months) improved left ventricle diastolic function, endothelial function, lowered the LDL-cholesterol level and protected against unfavorable hemorheological changes measured in post-infarction patients; ${ }^{17}$ and quercetin administered in a unique dose (400 $\mathrm{mg}$ ) promoted vasodilatation in healthy humans. ${ }^{16}$ For hypertensive patients, the ingestion of 65-153 mg of soy isoflavones per day (1-12 months) had an effect on lowering blood pressure. ${ }^{18}$

Several studies demonstrated that PC possess neuroprotective action (Table 2); anthocyanins, for instance, have shown ability to improve cognitive function lost by aging. ${ }^{20}$ The diary supplementation with anthocyanin-rich cherry juice $(200 \mathrm{~mL}$ day $^{-1}$ ) can lead to significant recuperation of dementia. ${ }^{20}$ Also, regarding the flavonoids, the administration of quercetin conjugated with superparamagnetic iron oxide nanoparticles (50-100 $\mathrm{mg} \mathrm{kg}^{-1}$ ) to rats was able to improve the animal's learning capacity and memory. ${ }^{21}$

The search for alternative therapeutics has led to numerous studies to evaluate the anticancer activity of PC against diverse tumour cell lines. ${ }^{1,2}$ PC have showed ability to inhibit the growth of different tumours; for instance, the flavonoids kaempferol, naringin and anthocyanins have significant activity on melanoma, oesophageal and breast carcinomas, respectively. ${ }^{22-24}$ Positive synergetic effects have also been detected with combined use of traditional therapeutic medicine and PC. For instance, luteolin has showed a synergetic effect when used with tumour necrosis factor-related apoptosis-inducing ligand (TRIAL) in the treatment of lung cancer, potentiating the effect of the drug in inhibiting tumour growth and increased apoptotic cell death. ${ }^{25}$ Similar synergetic effects were found in the combined use of doxorubicin, a chemotherapy drug, with naringin or orange-peel extract to treat oesophageal cancer in mice. ${ }^{24}$

\section{Phenolic compounds: industrial application}

PC have several biotechnological applications in different industries (Fig. 1B). Their exploitation is mainly due to their antioxidant, antimicrobial, and colouring properties, among others, especially explored for food preservation, by the food and packing industries, and in the cosmetics and also the textile industries.

\subsection{Food industry}

Facing the restrictions to the use of artificial food additives, the scientific community has been working on the development of natural alternatives.

The antioxidant and antimicrobial activities of PC exhibited by plant extracts have been crucial to the application of these compounds as preservatives, thus increasing the shelf-life of several foodstuffs. In Table 3, some practical applications of natural preservative additives are presented. For instance, the addition of phenolic extract obtained from Litchi chinensis Sonn. pericarp into sheep meat nuggets had similar inhibition of the lipid peroxidation to the one revealed by the synthetic antioxidant BHT (butylated hydroxyl toluene). ${ }^{26}$ Also, despite the degradation of PC with high temperature, the use of pheno-

Table 3 Applications of phenolic compounds in the food industry

\begin{tabular}{|c|c|c|c|c|}
\hline Phenolic compounds & Source & Product & Effects & Ref. \\
\hline \multicolumn{5}{|l|}{ Food Additives } \\
\hline \multirow[t]{6}{*}{ Phenolic extracts } & $\begin{array}{l}\text { Matricaria recutita } \mathrm{L} . \\
\text { Foeniculum vulgare Mill. }\end{array}$ & Yogurt & Antioxidant activity. & 28 \\
\hline & Olive live mill water & $\begin{array}{l}\text { Olive oil for the frying process of } \\
\text { French fries }\end{array}$ & $\begin{array}{l}\text { Preventing the deterioration of } \alpha \text {-tocopherol } \\
\text { and reducing the formation of acrolein and } \\
\text { hexanal. }\end{array}$ & 27 \\
\hline & Litchi chinensis Sonn. & Sheep meat nuggets & Antioxidant activity. & 26 \\
\hline & Rosmarinus officinalis $\mathrm{L}$. & Cottage cheese & Antioxidant activity. & 31 \\
\hline & Punica granatum L. peel & Ice cream & Antioxidant and $\alpha$-glucosidase activities. & 10 \\
\hline & Camellia sinensis $\mathrm{L}$. & Bread & Fortification with bioactive polyphenols. & 32 \\
\hline Hydroxycitric acid & $\begin{array}{l}\text { Garcinia cowa Roxb. ex } \\
\text { DC rind }\end{array}$ & Pasta & $\begin{array}{l}\text { Antioxidant activity and improvement of } \\
\text { sensory quality. }\end{array}$ & 53 \\
\hline Taxifolin & Commercial compound & Apple juice & Fortification with bioactive molecules. & 63 \\
\hline \multirow[t]{4}{*}{ Anthocyanins } & Euterpe edulis $\mathrm{M}$. & $\begin{array}{l}\text { Fermented and unfermented } \\
\text { beverages }\end{array}$ & Improvement of the colour. & 51 \\
\hline & Phaseolus vulgaris L. & Sport beverage & $\begin{array}{l}\text { Stable colour and fortification with bioactive } \\
\text { molecules. }\end{array}$ & 56 \\
\hline & Myrciaria cauliflora Mart. & Fresh sausage & $\begin{array}{l}\text { Improvement of colour, antioxidant and } \\
\text { antimicrobial activities. }\end{array}$ & 30 \\
\hline & Prunus nepalensis L. & $\begin{array}{l}\text { Yoghurt, syrup and hard-boiled } \\
\text { candy }\end{array}$ & Stable colour and sensory acceptance. & 29 \\
\hline $\begin{array}{l}\text { Catechin and epigallocatechin } \\
\text { gallate }\end{array}$ & Camellia sinensis $\mathrm{L}$. & Low-fat hard cheese & Antioxidant activity. & 62 \\
\hline
\end{tabular}
gallate 
lic extract obtained from Olea europaea L. residues in oil reduced the oxidation caused by a frying process $\left(180^{\circ} \mathrm{C}\right)$ in the production of French fries and preserved the vitamins (tocopherols) of oil used in the process for 6 hours, reduced the formation of unwanted compounds (acrolein and hexanal), and in contrast to the use of BHT as an antioxidant, promoted the production of acrylamide, which shows the advantage of these natural molecules in relation to artificial compounds. ${ }^{27}$ Higher protection against oxidative processes was also observed with the used PC obtained from Matricaria recutita L. and Foeniculum vulgare Mill. in comparison with potassium sorbate when added in the same concentration into yogurt; e.g. $\mathrm{EC}_{50}$ values to DPPH scavenging activity yogurts fortified with plant extracts were 45 and $94 \mathrm{mg} \mathrm{mL}^{-1}$, respectively, while the synthetic antioxidant showed an $\mathrm{EC}_{50}$ of $111 \mathrm{mg} \mathrm{mL}^{-1} .^{28}$

Anthocyanins are PC that provide attractive red-purple coloration to plant tissues; their use as a colouring additive is allowed by EFSA under code E163; however technological limitations, such as low stability and photodegradation, are some barriers to their industrial use. ${ }^{5}$ In contrast, satisfactory results have been obtained with the application of anthocyanins as colorants in several types of products (Table 3); for example anthocyanins from Prunus nepalensis L. added in high concentration into foods produced under different conditions, such as yoghurt, syrup and hard boiled candies, showed stable colour and improved the sensory acceptance of these products. ${ }^{29}$ In addition to their color capacity, anthocyanins can also provide biological benefits. For example, fresh sausages formulated with $2 \%-4 \%$ microencapsulated anthocyanins from Myrciaria cauliflora showed lower microbial degradation and greater antioxidant activity than a similar product formulated with carmine. ${ }^{30}$ Despite promising studies emphasizing PC potential as food additives, there is still a long way to their massive industrial application. Several studies are needed to evaluate the safe consumption of these substances and obtain their approval by the regulatory authorities e.g. FDA (Food and Drug Administration, in the United States) and EFSA (European Food Safety Authority, in the European Union). Unfortunately, only a limited number of natural additives based on PC are legislated. As far as we know, authorized PC used as food additives include catechin (allowed in the US and EU (E300)) and ferulic acid (in Japan) as antioxidants, and anthocyanins as mentioned before. ${ }^{5}$

PC have also been used in processed foods to enhance their functional properties and provide consumer health benefits. In this context, Rosmarinus officinalis L. extract has increased the antioxidant activity in cottage cheese, ${ }^{31}$ and $C$. sinensis polyphenols have improved the bioactive profile of bread and cheese, ${ }^{32,33}$ and the addition of $P$. granatum extract into ice cream provided functional properties to product, namely antioxidant and $\alpha$-glucosidase inhibitory activities, without changing its sensory acceptance. ${ }^{10}$

\subsection{Cosmetic industry}

As well as in the food industry, the cosmetics industry has also been exploiting natural additives as alternatives to the artificial ones. ${ }^{7,34}$ In this context, PC have showed potential for use as bioactive ingredients in cosmeceutical products. ${ }^{3}$

PC can absorb ultraviolet radiation due to the presence of chromophores in their structure, avoiding the penetration of solar radiation into the skin. UV protection has been described for some PC, such as quercetin, resveratrol and hydroxycinnamic acids, which presented a sun protection factor (SPF) ranging from 7 to $30 .^{34}$

As is well known, free radicals can lead to early aging due to several interactions that reactive oxygen species can make with proteins of the skin, as well as active enzymes such as collagenase, elastase, and tyrosinase, resulting in the degradation of collagen and elastin. Against these skin lesions, a body cream formulated with phenolic extract of Nymphaea rubra Roxb was effective on skin wrinkle reduction and skin whitening with no irritation efficiency in healthy volunteers after 60 days of use; these benefits obtained on the volunteers' skin were correlated with the high antioxidant activity of the extract (IC $_{50} 0.075$ and $0.273 \mathrm{mg} \mathrm{mL}{ }^{-1}$ for DPPH and ABTS assays, respectively) and with its tyrosinase inhibitory activity $\left(\mathrm{IC}_{50}=\right.$ $\left.3.285 \mathrm{mg} \mathrm{mL}^{-1}\right){ }^{35}$

Hydroxycinnamic acids, namely $p$-hydroxybenzoic, $p$-coumaric, and protocatechuic acids, have showed high stability, for a long time (6 months) when added to a semi-solid base cream and maintain the anti-tyrosinase, anti-inflammatory and antimicrobial activities, making them suitable to be explored as multifunctional cosmeceutical ingredients. ${ }^{7}$

\subsection{Packaging industry}

Some PC have also been used to elaborate packaging formulations with antioxidant and antimicrobial properties. ${ }^{9,36}$ As anthocyanins are PC with interesting colour properties and high antioxidant activity these flavonoids are able to prevent the lipid oxidation of olive oil when added to the packing formulation. ${ }^{36}$ Moreover, the colour of anthocyanins depends on the $\mathrm{pH}$, ranging from red $(\mathrm{pH} \sim 2)$ to green $(\mathrm{pH} \sim 11)$, which enable the fabrication of films that are susceptible to $\mathrm{pH}$ changes such as the film based on gelatin/polyvinyl alcohol developed with anthocyanins from mulberry (Morus sp.) to assess fish spoilage by changing the colour of the packaging from purple (fresh fish) to brown (fish after $18 \mathrm{~h}$ ), and finally dark green after $24 \mathrm{~h} .{ }^{9}$ Phenolic acids, namely gallic and caffeic acids, have been used in chitosan-based biofilms to inhibit the growth of Bacillus subtilis and Staphylococcus aureus, in addition to improving physical characteristics, such as vapor and oxygen permeability of the film. ${ }^{37}$ Tannins interact with proteins through hydrogen bonding or noncovalent bonds; this property was explored to develop protein-based biofilms with tannins that have antioxidant and antimicrobial activity against Escherichia coli and Listeria innocua. $^{38}$

\subsection{Textile industry}

The textile industry is one of the highest polluters, since high amounts of water are contaminated with a heavy load of chemicals. On the other hand, allergic reactions also have 
been associated with synthetic dyes. ${ }^{8,39}$ In this scenario, the interest in the use of PC as natural dyes with high biodegradability has grown. ${ }^{8,39}$ In addition to being less aggressive to the environment, natural dyes obtained from oak (Quercus sp.) bark, mostly composed of gallotannin, ellagitannin, quercetin and quercetin-3-O-glucoside, and from red, black and green tea extracts, showed UV protection when applied in Tussah silk and cotton, respectively. ${ }^{8,39}$ Antimicrobial activity against $E$. coli and $S$. aureus was also achieved with the use of natural dye from oak bark. ${ }^{8}$

\section{Challenges for the use of phenolic compounds by industries}

The previous topics showed the potential of the PC for various applications in different industry segments. However, for the practical and viable use of these molecules, some barriers need to be overcome; for example the low concentration of these compounds found in plant tissues can be a limiter to meet their high demand by the industries; also their sensitivity to various environmental factors, such as light and heat, can lead to their degradation and, consequently, the loss of their bioactivities. Furthermore, for efficient use as a therapeutic and functional agent, bioavailability features need to be better understood and improved.

\subsection{Sustainable production of phenolic compounds}

5.1.1. Elicitation. Elicitation is a technique that causes a stress condition, e.g. salinity, nutrient deficiency, excessive radiation (UV), extreme cold or hot temperatures, and the presence of microorganisms, which leads to an increasing production of secondary metabolites in the plants. ${ }^{40}$ In Table 4 are presented some studies of the enrichment of phenolics in plants through elicitation. This technique has led to a high increase of the concentration of PC with regard to control plants, such as the case of oxyresveratrol of Morus alba L. callus that increased more than 730-fold with the addition of 2-hydroxypropyl- $\beta$-cyclodextrin to the culture media. ${ }^{41}$ Also, the elicitation technique has showed improvement in the bioactivities of the extract plants, which can be correlated with the enrichment in PC. In a recent study, Złotek et al. ${ }^{40}$ compared the effect of two abiotic elicitors, arachidonic (AA) and jamonic acids (JA), to increase the phenolic composition and bioactivities of Triticum aestivum L. According to the results, the AA elicitation had higher impact on flavone content, while the JA elicitor was more favourable for phenolic acid production. Regarding the bioactivities, higher antioxidant and anti-inflammatory activities were achieved with AA. On the other hand, JA had no positive effect on the lipoxygenase inhibition. A JA derivative, methyl jasmonate, also increased the antioxidant activity of Allium cepa L., in addition to its increased quercetin concentration. ${ }^{42}$

Table 4 Alternatives for the sustainable production of phenolic compounds: (1) Plant cell elicitation; and (2) metabolic engineering of microorganisms

\begin{tabular}{|c|c|c|c|c|c|}
\hline \multicolumn{2}{|l|}{ Phenolic compound } & Plant tissue & Elicitor & Increased of yield & Ref. \\
\hline \multicolumn{6}{|l|}{ (1) Elicitation } \\
\hline \multicolumn{2}{|l|}{ Phenolic acids } & Centella asiatica $\mathrm{L}$ & Methyl jasmonate & 122-Fold & 81 \\
\hline \multicolumn{2}{|l|}{ Flavonoids } & & & 22.4-Fold & \\
\hline \multirow{2}{*}{\multicolumn{2}{|c|}{$\begin{array}{l}\text { Flavonols } \\
\text { Anthocvanins }\end{array}$}} & Vitis vinifera $\mathrm{L}$. & Ascophyllum nodosum extract & $112 \%-308 \%$ & 82 \\
\hline & & Vitis vinifera L. cv. Tinto Cão & Chitosan & $47 \%-82.45 \%$ & 83 \\
\hline \multicolumn{2}{|l|}{ Catechin } & & & $133.33 \%$ & \\
\hline \multicolumn{2}{|l|}{ Flavonols } & & & $59.0 \%-105.8 \%$ & \\
\hline \multicolumn{2}{|l|}{ Rosmarinic acid } & Melissa officinalis $\mathrm{L}$. & Heat stress & $59 \%$ & 84 \\
\hline \multirow{2}{*}{\multicolumn{2}{|c|}{$\begin{array}{l}\text { Resveratrol } \\
\text { Oxyresveratrol }\end{array}$}} & Morus alba $\mathrm{L}$. & \multirow[t]{2}{*}{ 2-Hydroxypropyl- $\beta$-cyclodextrin } & 43-Fold & 41 \\
\hline & & & & 730-Fold & \\
\hline \multirow{5}{*}{\multicolumn{2}{|c|}{$\begin{array}{l}\text { Flavones } \\
\text { Luteolin 6-C-hexoside- } O \text {-hexoside } \\
\text { Luteolin 6- } C \text {-hexoside } \\
\text { Luteolin } O \text {-deoxyhexoside- } C \text {-hexoside } \\
\text { Apigenin } O \text {-hexoside- } O \text {-hexoside }\end{array}$}} & Triticum aestivum $\mathrm{L}$. & Arachidonic acid & $35 \%-58 \%$ & 40 \\
\hline & & & & $37 \%$ & \\
\hline & & & & $44 \%$ & \\
\hline & & & & $58 \%$ & \\
\hline & & & & $41 \%$ & \\
\hline \multicolumn{2}{|c|}{ Vanilic acid } & & Jasmonic acid & $94 \%$ & \\
\hline \multirow{2}{*}{\multicolumn{2}{|c|}{$\begin{array}{l}\text { Syringic acid } \\
\text { Sinapic acid }\end{array}$}} & & & $47 \%$ & \\
\hline & & & & $77 \%$ & \\
\hline \multicolumn{2}{|l|}{ Quercetin } & Allium cepa $\mathrm{L}$. & Methyl jasmonate & 13.9-Fold & 42 \\
\hline Phenolic compound & Subs & & Microorganism & & Ref. \\
\hline \multicolumn{6}{|c|}{ (2) Metabolic engineering } \\
\hline Naringerin & \multicolumn{2}{|c|}{ Glucose $/ p$-coumarate supplementation } & E. coli & $412 \mathrm{mg} \mathrm{L}^{-1}$ & 85 \\
\hline Flavan-3-ols & \multicolumn{2}{|c|}{ Glucose } & E. coli & $40.7 \mathrm{mg} \mathrm{L}^{-1}$ & 86 \\
\hline Kaempferol & \multicolumn{2}{|c|}{ Glucose } & S. cerevisiae & $26.57 \mathrm{mg} \mathrm{L}^{-1}$ & 87 \\
\hline Quercetin & \multicolumn{2}{|c|}{ Glucose } & S. cerevisiae & $20.38 \mathrm{mg} \mathrm{L}^{-1}$ & 87 \\
\hline \multirow[t]{2}{*}{ Resveratrol } & Gluc & ethanol & S. cerevisiae & $-531.41 \mathrm{mg} \mathrm{L}^{-1}$ & 43 \\
\hline & Glice & & E. coli & $\mathrm{L}^{-1}$ & 44 \\
\hline
\end{tabular}


5.1.2. Metabolic engineering (MBE). Metabolic engineering (MBE) of microorganisms is another interesting method to produce PC, with an advantage of not requiring complex extraction and purification methods like those used in the obtaining of these compounds from plant materials. ${ }^{6}$ This biotechnology process is based on de novo synthesis, in which occurs the biotransformation of one substance into a new compound. The biosynthesis of PC in metabolic pathways in microorganisms, namely in Escherichia coli and Saccharomyces cerevisiae, has led to heterologous production of diverse PC. In Table 4 are presented results obtained with studies focused in polyphenol production by MBE of microorganisms.

MBE can be a viable economic alternative for the production of PC; however, in some cases the medium supplementation may be expensive/unable for industry, such as the use of $p$-coumarin acid as a precursor of target compounds. In this point, some studies have proposed the de novo biosynthesis from a cheap source of carbon. For instance, Li et $a l^{43}$ achieved high production of resveratrol by metabolic $S$. cerevisiae from glucose or ethanol (415.65 and $531.41 \mathrm{mg}$ $\mathrm{L}^{-1}$, respectively), through the tyrosine pathway. The use of coculture with two $E$. coli modified strains also made possible the formation of this bioactive stilbene from glycerol. ${ }^{44}$ Naringenin, a central precursor of the majority of the flavonoids, also has been produced from xylose via a coculture system composed of $E$. coli and $S$. cerevisiae. ${ }^{45}$

\subsection{Stability of phenolic compounds}

To improve the PC stability, several techniques, such as the ones presented in Table 5, have been developed.

Encapsulation is one of the most used techniques to protect PC of the degradation. Diverse methods, such as spray drying (SD), freeze drying (FD), and complex coacervation, have been applied to obtain encapsulated PC. ${ }^{46,47} \mathrm{SD}$ and FD are the most applied techniques to encapsulate phytochemicals obtained from plant tissues; SD has the main advantages of being a fast process, with continuous production, and being simple and easy to increase, while FD is also a simple process, which requires low operating temperature and the absence of air, factors that result in less oxidative degradation and change in the structure of compounds; ${ }^{48,49}$ however, these systems operate under extremely different conditions, and different encapsulation produces with distinct features. ${ }^{46,48}$ For example, in the encapsulation of green tea extract using maltodextrin, $\beta$-cyclodextrin or their combination as wall materials, encapsulation by SD showed a smaller size and more regular format than FD. This behaviour was already expected, since the formation of microspheres by SD occurs instantly by pulverization of a solution in the hot surface. On the other hand, in the FD technique, the formation of ice is slow, which allows the formation of irregular structures. However, the efficiency of FD was higher than that of SD. ${ }^{32}$ Similar results were found in the encapsulation of bioactive compounds obtained from Hibiscus acetosella Welw. ${ }^{46}$ In these studies, this fact was explained due to the phenolic degradation by high temperature. $^{32,46}$ Increasing the drying temperature can also decrease the antioxidant capacity of bioactive compounds. ${ }^{48}$ Furthermore, the thermal sensitivity of the target compound is crucial for the choice of the encapsulation method and wall material. ${ }^{48,49}$

The composition of the encapsulating agent also has impact on the physicochemical properties of the microencapsulated compounds, such as the particle size, porosity, water activity, dissolution rate, degradation rate, thermal resistance, and interaction with other substance, among others. Diverse materials have been used in the literature, since derivatives from hydrolysate starches are one of the most applied agents as wall materials due to their ability to improve aqueous solubility, low viscosity and being easy to dry. ${ }^{50}$ High efficiency was achieved with pure $\mathrm{MD}$ in the microencapsulation of green tea and P. granatum polyphenols. ${ }^{10,32}$ For anthocyanic compounds, this polysaccharide revealed promising results in the protection against thermal degradation and colour loss during storage. ${ }^{11,51}$ Modified starches with octenyl succinic anhydride (OSA) combined with inulin, a fructooligosaccharide capable of improving viscoelastic properties and providing prebiotic activity of the particles, have been used to protect polyphenols during the baking process of cake without changing the product quality. ${ }^{52}$ For PC, this blend of polymers with MD has improved mainly the stability to heating. ${ }^{53,54}$ However, the behaviour of each class of PC can be different depending on the wall material composition. For instance, different blends of proteins with maltodextrin (soybean-maltodextrin (SP-MD) and whey protein-maltodextrin (WP-MD)) were tested to improve the stability of PC from grape juice, namely anthocyanins, flavanols, hydroxycinnamic acid derivatives and flavan-3-ols. As a result, the SP-MD system was the most efficient for anthocyanin stability. On the other hand, flavanols showed higher stability with the WM-MD system; however, both systems were unable to improve the stability of phenolic acids and flavan-3-ols. ${ }^{54}$ Zein, a protein with high thermal resistance (until $200^{\circ} \mathrm{C}$ ), has been applied by electrospraying for encapsulation of polyphenols from Euterpe oleracea Mart. to protect them from thermal degradation during sterilization and baking processes. ${ }^{55}$

In particular, anthocyanin co-pigmentation has been shown to be an efficient way to achieve stability; molecular interaction of anthocyanins with other compounds leads to the accumulation of acyl in the pyran ring, which reduces the sensitivity of this flavonoids to the nucleophilic attack of water, consequently preventing anthocyanins from forming chalcones and losing their colour. Co-pigmentation of anthocyanins with phenolic acids, catechin and $\beta$-cyclodextrin has been proposed to increase the thermal stability and colour intensity of these compounds. ${ }^{56,57}$

In addition to increasing the stability and resistance to diverse factors of PC, encapsulation techniques can also mask some sensorial changes, such as taste modification and astringency, resulting from the addition of these compounds to a food matrix. ${ }^{47,58}$ Also, an improvement of the bioavailability of these molecules has been achieved by these technologies. ${ }^{55,59-63}$ Therefore, the complexity of each phytochemical, associated with the selected wall material and their 
Table 5 Methods to improve the stability/bioavailability of phenolic compounds

\begin{tabular}{|c|c|c|c|c|c|}
\hline Encapsulation technique & Carrier materials & Phenolic compounds & Source & Effects & Ref. \\
\hline \multirow[t]{2}{*}{ Complex coacervation } & Gelatin/к-carrageenan & Phenolic extract & \multirow[t]{2}{*}{ Cinnamon bark } & Improving stability, resistance & \multirow[t]{2}{*}{47} \\
\hline & Gelatin-GA & Phenolic extract & & $\begin{array}{l}\text { to processing and masking of } \\
\text { astringency. }\end{array}$ & \\
\hline \multirow[t]{2}{*}{ Atomization/coagulation } & CA & Phenolic extract & $\begin{array}{l}\text { Rosmarinus officinalis } \\
\text { L. }\end{array}$ & Protection of bioactivities. & 31 \\
\hline & $\mathrm{NaAlg}-\mathrm{CaCl}_{2}$ & $\begin{array}{l}p \text {-Hydroxybenzoic, } \\
p \text {-coumaric, and } \\
\text { protocatechuic acids }\end{array}$ & $\begin{array}{l}\text { Commercial } \\
\text { compounds }\end{array}$ & Protection of bioactivities. & 7 \\
\hline \multirow[t]{3}{*}{ Inclusion complex } & $\beta-\mathrm{CD}$ & Catechin & $\begin{array}{l}\text { Commercial } \\
\text { compound }\end{array}$ & $\begin{array}{l}\text { Increased solubility and } \\
\text { resistance to heat, light and } \\
\text { oxygen. }\end{array}$ & 88 \\
\hline & & Anthocyanins & Rubus fruticosus $\mathrm{L}$. & $\begin{array}{l}\text { Thermal resistance and } \\
\text { stability after simulated } \\
\text { gastrointestinal digestion. }\end{array}$ & 89 \\
\hline & $\gamma-\mathrm{CD}$ & Taxifolin & $\begin{array}{l}\text { Commercial } \\
\text { compound }\end{array}$ & $\begin{array}{l}\text { Increase in bioavailability (3.72- } \\
\text { fold) in rats. }\end{array}$ & 75 \\
\hline \multirow[t]{9}{*}{ Spray drying } & OSA-starch and insulin & Phenolic extract & $\begin{array}{l}\text { Bertholletia excelsa } \mathrm{H} . \\
\text { B.K }\end{array}$ & High stability (120 days). & 52 \\
\hline & MD & Phenolic extract & Punica granatum L. & $\begin{array}{l}\text { Stability to storage }\left(4^{\circ} \mathrm{C} \text { per } 90\right. \\
\text { days), and protection of } \\
\text { bioactivities. }\end{array}$ & 10 \\
\hline & $\mathrm{MD}$ & Anthocyanins & $\begin{array}{l}\text { Euterpe edulis } \mathrm{M} . ; \\
\text { Myrciaria cauliflora } \\
\text { Mart. }\end{array}$ & $\begin{array}{l}\text { Protection of colour and } \\
\text { bioactivities. }\end{array}$ & $\begin{array}{l}30 \\
\text { and } \\
51\end{array}$ \\
\hline & MD-GA & Anthocyanins & Cherry juice & $\begin{array}{l}\text { Colour stability at } 38^{\circ} \mathrm{C} \text { per } 60 \\
\text { days. }\end{array}$ & 90 \\
\hline & MD-WP & Catechin & Grape juice & $\begin{array}{l}\text { Improvement of thermal } \\
\text { resistance }\end{array}$ & 54 \\
\hline & $\mathrm{MD}-\mathrm{SP}$ & Anthocyanins & Grape juice & $\begin{array}{l}\text { improvement of thermal } \\
\text { resistance; protection of colour } \\
\text { and antioxidant activity ( } 150 \\
\text { days). }\end{array}$ & 54 \\
\hline & WP & Hydroxycitric acid & Garcinia Cowa Roxb. & $\begin{array}{l}\text { Retained the antioxidant } \\
\text { activity after the baking } \\
\text { process. }\end{array}$ & 53 \\
\hline & $\mathrm{NaAlg}-\mathrm{CaCO}_{3}$ & Anthocyanins & Grape skin & $\begin{array}{l}\text { Stability to light and heat; } \\
\text { increased bioaccessibility. }\end{array}$ & 61 \\
\hline & MD-PEC & Phenolic extract & Crocus sativus L. petals & $\begin{array}{l}\text { High stability, protection of } \\
\text { antioxidant activity, and } \\
\text { improved bioaccessibility. }\end{array}$ & 59 \\
\hline \multirow[t]{4}{*}{ Freeze drying } & $\mathrm{MD} / \beta-\mathrm{CD}$ & Phenolic extract & Camellia sinensis L. & $\begin{array}{l}\text { Retained the antioxidant } \\
\text { activity. }\end{array}$ & 32 \\
\hline & $\mathrm{MD}$ & Anthocyanins & $\begin{array}{l}\text { Myrciaria cauliflora } \\
\text { pomace }\end{array}$ & $\begin{array}{l}\text { Thermal stability up to } 150^{\circ} \mathrm{C} \text {; } \\
\text { maintained stable colour up to } \\
226 \text { days. }\end{array}$ & 11 \\
\hline & SP-GA & Anthocyanins & Rubus idaeus L. & $\begin{array}{l}\text { High stability }\left(37^{\circ} \mathrm{C} \text { per } 60\right. \\
\text { days); improved } \\
\text { bioaccessibility. }\end{array}$ & 60 \\
\hline & GA & Phenolic extract & Hibiscus acetosella & Thermal stability. & 46 \\
\hline Electrospraying & Zein & Phenolic extract & Euterpe oleracea Mart. & $\begin{array}{l}\text { Thermal stability (up to } 180^{\circ} \mathrm{C} \text { ) } \\
\text { and improved bioaccessibility. }\end{array}$ & 55 \\
\hline \multirow[t]{2}{*}{ Microemulsion } & Labrasol & Anthocyanins & $\begin{array}{l}\text { Commercial } \\
\text { compounds and } \\
\text { Vaccinium } \\
\text { angustifolium Aiton }\end{array}$ & Improved bioaccessibility. & 14 \\
\hline & Lecithin & Tangeretin & $\begin{array}{l}\text { Commercial } \\
\text { compound }\end{array}$ & Improved bioaccessibility. & 71 \\
\hline \multirow[t]{5}{*}{ Nanoliposomes } & SL & $\begin{array}{l}\text { Catechin and } \\
\text { epigallocatechin gallate }\end{array}$ & $\begin{array}{l}\text { Commercial } \\
\text { compounds }\end{array}$ & $\begin{array}{l}\text { Improvement of the stability } \\
\text { and antioxidant activity. }\end{array}$ & 62 \\
\hline & MD and chitosan & Anthocyanins & Morus nigra $\mathrm{L}$. & $\begin{array}{l}\text { Stability to heat and } \mathrm{pH} \\
\text { changes, improved } \\
\text { bioavailability. }\end{array}$ & 64 \\
\hline & $\begin{array}{l}\text { Soybean } \\
\text { phosphatidylcholine/ } \\
\text { cholesterol }\end{array}$ & Phenolic extract & Coconut husk & $\begin{array}{l}\text { Improved bioactivities; masked } \\
\text { the brown dark colour. }\end{array}$ & 58 \\
\hline & Tween 80, SL & Taxifolin & $\begin{array}{l}\text { Commercial } \\
\text { compound }\end{array}$ & $\begin{array}{l}\text { Improved stability, antioxidant } \\
\text { activity, and bioavailability. }\end{array}$ & 63 \\
\hline & Lecithin & Phenolic extract & Camellia sinensis L. & $\begin{array}{l}\text { Increased stability and } \\
\text { preserved antioxidant activity. }\end{array}$ & 91 \\
\hline
\end{tabular}


Table 5 (Contd.)

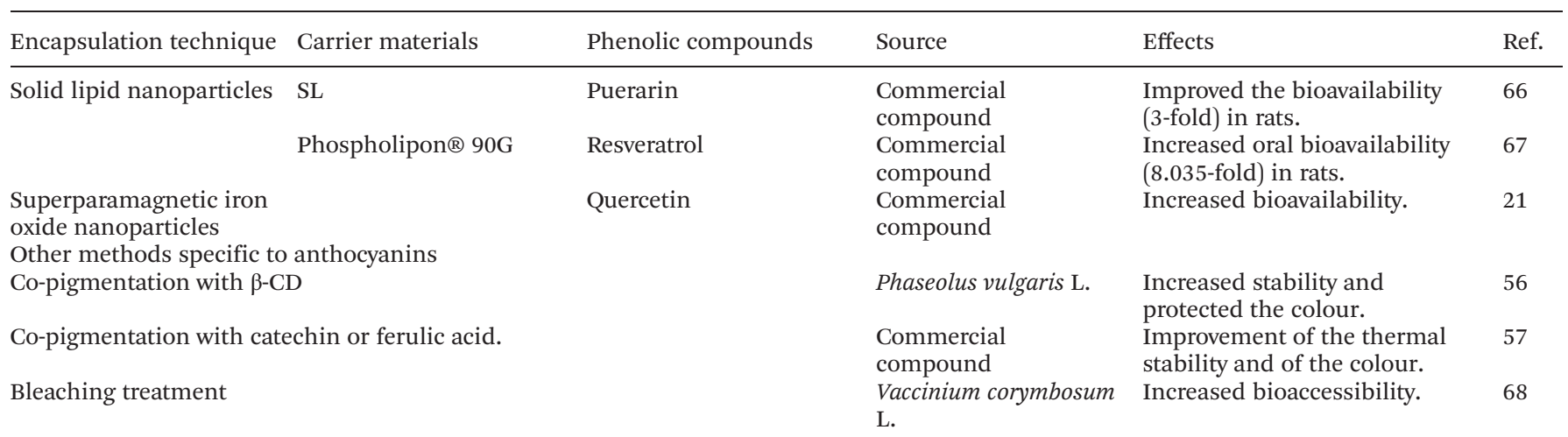

MD - Maltodextrin; GA - gum arabic; SPI - soybean protein; WP - whey protein; CA - calcium alginate; MMS - modified maize starch; CD -

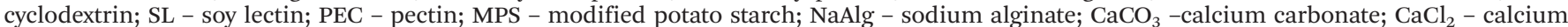
chloride.

interaction with other compounds, makes the choice of the encapsulation technique more appropriate in a thorough and individual study.

\subsection{Bioavailability of phenolic compounds}

PC are recognized and treated by the body in the same way as xenobiotics, being metabolized so that they are rapidly excreted. These compounds must be absorbed and distributed through the body's bloodstream and/or lymphatic systems; ${ }^{4}$ the amount of compounds available to undergoe this process is known as bioavailability. In general, PC have low bioavailability, so it is estimated that the rate of absorption of $\mathrm{CP}$ ranges from 0.3 to $43 \% .{ }^{1,4}$ Furthermore, when a PC is ingested, another factor, denoted as bioaccessibility, which corresponds to the fraction of a compound that is released from the food matrix to the gastrointestinal tract and becomes available for the absorption process, must also be considered. ${ }^{4}$ Therefore, several aspects can influence bioaccessibilitiy of these compounds, such as the chemical structure, water solubility, food processing, interaction with other compounds, and dietary intake, among others. ${ }^{4}$ Besides the mentioned factors, the bioavailability is also influenced by the digestion and metabolization process, where these compounds are subjected to various chemical changes, namely biotransformation. ${ }^{4,12}$ These processes can change the PC structures, which interfere in the reactions and may interfere with the next stages of the absorption process. Complex PC, such as hydrolysable and condensed tannins, must be hydrolysed into smaller molecules (tri, di and monomers) to be absorbed; enzymatic reactions that occur at the level of small intestine are not able to break these molecules, being then taken to the large intestine, where only bacterial fermentation reduces these PC; only after this process, the hydrolysed compounds are transported to the liver or are excreted. ${ }^{4,12}$

Facing the complexity of PC absorption, different techniques are being developed to minimize the PC interactions described above, improving chemical protection and targeted delivery (Table 5). Nanoencapsulation techniques using appropriate wall materials have showed potential to protect the polyphenols of the metabolic reactions; besides that they allow the selection of the desired effect or specific tissue on which these compounds should exert their actions. ${ }^{4}$ For example, the change of $\mathrm{pH}$ values is a factor that interferes in the anthocyanin's stability, which can lead to their degradation under gastrointestinal conditions ( $\mathrm{pH}$ 2-6.8). To improve the resistance of these compounds during digestion and their bioavailability, encapsulation by emulsification with $\mathrm{NaAlg}$ and $\mathrm{CaCO}_{3}$ by freeze or spray drying showed a retention efficiency of $70 \%$ and $83 \%$ after in vitro gastric digestion, and $24.5 \%$ and $15 \%$ in the end of intestinal digestion, respectively. ${ }^{61}$ The use of nanoliposomes is another technique that can be used to improve the stability of $\mathrm{PC}$ in alkaline $\mathrm{pH}^{4}$ By this method, it was possible to keep the encapsulated anthocyanins stable up to $\mathrm{pH} 7.5 .{ }^{64}$ Electrospray encapsulation with zein protein also has showed protection against low $\mathrm{pH}$ to $\mathrm{PC}$ from E. oleracea. ${ }^{55}$ Lipid-based nanocarriers, e.g. nano-emulsions, nano-liposomes, solid lipids and nanoparticles, have shown promise to increase the bioaccessibility of phenolic compounds in the body due to their capacity to improve solubility, stability on gastric condition and release of these compounds in a controlled way. ${ }^{65}$ For example, solidlipid nanoparticles have been used to improve absorption of PC that have poor water-solubility. ${ }^{65-67}$ In addition, this technique associated with purified phosphatidylcholine (Phospholipon ${ }^{\circledR}$ 90G) as the encapsulation material was able to preserve the integrity of resveratrol at low stomach $\mathrm{pH}^{67}$

Interesting, besides technological techniques, simple methods can also be used to increase the bioavailability of PC. For instance, anthocyanins' absorption from highbush blueberry (Vaccinium corymbosum L.) purée in the human body has been improved after bleaching as pre-treatment. ${ }^{68}$

\section{Concluding remarks and future perspectives}

Several studies have presented PC as a natural alternative for the treatment and prevention of several diseases, such as 
cancer, cardiovascular disorders and neurodegeneration; in addition, these compounds can be used in the formulation of cosmetics that act on pathologies or conditions harmful to the skin, which increase the interest in the use of these bioactive molecules in pharmaceutical products. PC are an alternative to artificial food additives and can be interesting for the development of functional foods that aim to maintain good health. However, there are still some gaps that need to be better studied so that the use of these compounds can reach a large industrial scale and for their administration and consumption to be effective and efficient to guarantee their benefits without causing a side effect. Still for application in the food industry, methods to increase the stability and to preserve the bioactivity of these compounds during the useful life of food products must be investigated.

As presented in this review, more effective methods for the viable use of these compounds have been developed, which makes us believe that the practical application of these natural molecules tends to become more frequent in different industries, such as pharmaceutical, food, cosmetics, textile and others.

\section{Conflicts of interest}

The authors declare no conflict of interest.

\section{Acknowledgements}

Foundation for Science and Technology (FCT, Portugal) is acknowledged for financial support by national funds FCT/ MCTES to CIMO (UIDB/00690/2020). National funding by FCT, P. I., through the institutional scientific employment programcontract for Lillian Barros contract and through the individual scientific employment program-contract for Sandrina A. Heleno, and B. Albuquerque Research grant (SFRH/BD/ 136370/2018). European Regional Development Fund (ERDF) through the Regional Operational Program North 2020, within the scope of Project NORTE-01-0145-FEDER-023289: DeCodE and project Mobilizador Norte-01-0247-FEDER-024479: ValorNatural ${ }^{\circledR}$. FEDER-Interreg España-Portugal programme is acknowledged for financial support through the project 0377_Iberphenol_6_E.

\section{References}

1 C. Caleja, A. Ribeiro, M. F. Barreiro and I. C. F. R. Ferreira, Phenolic compounds as nutraceuticals or functional food ingredients, Curr. Pharm. Des., 2017, 23, 2787.

2 A. Durazzo, E. Caiazzo, M. Lucarini, C. Cicala, A. A. Izzo, E. Novellino and A. Santini, Polyphenols: a concise overview on the chemistry, occurrence, and human health, Phytother. Res., 2019, 33, 2221-2243.
3 M. L. Soto, E. Falqué and H. Domínguez, Relevance of natural phenolics from grape and derivative products in the formulation of cosmetics, Cosmetics, 2015, 259-276.

4 J. A. Domínguez-Avila, A. Wall-Medrano, G. R. VelderrainRodríguez, C.-Y. O. Chen, N. J. Salazar-López, M. RoblesSánchez and G. A. González-Aguilar, Gastrointestinal interactions, absorption, splanchnic metabolism and pharmacokinetics of orally ingested phenolic compounds, Food Funct., 2017, 8, 15-38.

5 M. Carocho, P. Morales and I. C. F. R. Ferreira, Natural food additives: Quo vadis?, Trends Food Sci. Technol., 2015, 45, 284-295.

6 R. Mark, X. Lyu, J. J. L. Lee, R. Parra-Saldívar and W. N. Chen, Sustainable production of natural phenolics for functional food applications, J. Funct. Foods, 2019, 57, 233-254.

7 O. Taofiq, S. A. Heleno, R. C. Calhelha, I. P. Fernandes, M. J. Alves, L. Barros, A. M. González-Paramás, I. C. F. R. Ferreira and M. F. Barreiro, Phenolic acids, cinnamic acid, and ergosterol as cosmeceutical ingredients: Stabilization by microencapsulation to ensure sustained bioactivity, Microchem. J., 2019, 147, 469-477.

8 Y. Jia, B. Liu, D. Cheng, J. Li, F. Huang and Y. Lu, Dyeing characteristics and functionability of tussah silk fabric with oak bark extract, Text. Res. J., 2017, 87, 1806-1817.

9 P. Zeng, X. Chen, Y.-R. Qin, Y.-H. Zhang, X.-P. Wang, J.-Y. Wang, Z.-X. Ning, Q.-J. Ruan and Y.-S. Zhang, Preparation and characterization of a novel colorimetric indicator film based on gelatin/polyvinyl alcohol incorporating mulberry anthocyanin extracts for monitoring fish freshness, Food Res. Int., 2019, 126, 108604.

10 M. Çam, N. C. İçyer and F. Erdoğan, Pomegranate peel phenolics: microencapsulation, storage stability and potential ingredient for functional food development, Lebensm.-Wiss. Technol., 2014, 55, 117-123.

11 A. C. P. Souza, P. D. Gurak and L. D. F. Marczak, Maltodextrin, pectin and soy protein isolate as carrier agents in the encapsulation of anthocyanins-rich extract from jaboticaba pomace, Food Bioprod. Process., 2017, 102, 186-194.

12 S. A. Heleno, A. Martins, M. J. R. P. Queiroz and I. C. F. R. Ferreira, Bioactivity of phenolic acids: metabolites versus parent compounds: a review, Food Chem., 2015, 173, 501-513.

13 S. Seyyedebrahimi, H. Khodabandehloo, E. Nasli and R. Meshkani, The effects of resveratrol on markers of oxidative stress in patients with type 2 diabetes : a randomized, double - blind, placebo - controlled clinical trial, Acta Diabetol., 2018, 55, 341-353.

14 M. H. Grace, D. M. Ribnicky, P. Kuhn, A. Poulev, S. Logendra, G. G. Yousef, I. Raskin and M. A. Lila, Hypoglycemic activity of a novel anthocyanin-rich formulation from lowbush blueberry, Vaccinium angustifolium Aiton, Phytomedicine, 2009, 16, 406-415.

15 A. Abdel-Moneim, A. I. Yousef, S. M. Abd El-Twab, E. S. Abdel-Reheim and M. B. Ashour, Gallic acid and 
p-coumaric acid attenuate type 2 diabetes-induced neurodegeneration in rats, Metab. Brain Dis., 2017, 32, 12791286.

16 A. Perez, S. Gonzalez-Manzano, R. Jimenez, R. Perez-Abud, J. M. Haro, A. Osuna, C. Santos-Buelga, J. Duarte and F. Perez-Vizcaino, The flavonoid quercetin induces acute vasodilator effects in healthy volunteers: Correlation with beta-glucuronidase activity, Pharmacol. Res., 2014, 89, 1118.

17 K. Magyar, R. Halmosi, A. Palfi, G. Feher, L. Czopf, A. Fulop, I. Battyany, B. Sumegi, K. Toth and E. Szabados, Cardioprotection by resveratrol: A human clinical trial in patients with stable coronary artery disease, Clin. Hemorheol. Microcirc., 2012, 50, 179-187.

18 X. X. Liu, S. H. Li, J. Z. Chen, K. Sun, X. J. Wang, X. G. Wang and R. T. Hui, Effect of soy isoflavones on blood pressure: A meta-analysis of randomized controlled trials, Nutr. Metab. Cardiovasc. Dis., 2012, 22, 463-470.

19 X. Zhang, Y. Zhu, F. Song, Y. Yao, F. Ya, D. Li, W. Ling and Y. Yang, Effects of purified anthocyanin supplementation on platelet chemokines in hypocholesterolemic individuals: a randomized controlled trial, Nutr. Metab., 2016, 13, 1-12.

20 K. Kent, K. Charlton, S. Roodenrys, M. Batterham, J. Potter, V. Traynor, H. Gilbert, O. Morgan and R. Richards, Consumption of anthocyanin-rich cherry juice for 12 weeks improves memory and cognition in older adults with mildto-moderate dementia, Eur. J. Nutr., 2017, 56, 333-341.

21 E. Amanzadeh, A. Esmaeili, R. Enteshari and N. Abadi, Quercetin conjugated with superparamagnetic iron oxide nanoparticles improves learning and memory better than free quercetin via interacting with proteins involved in LTP, Sci. Rep., 2019, 9, 1-19.

22 S.-H. Kim, K.-A. Hwang and K.-C. Choi, Treatment with kaempferol suppresses breast cancer cell growth caused by estrogen and triclosan in cellular and xenograft breast cancer models, J. Nutr. Biochem., 2016, 28, 70-82.

23 C.-C. Su, C.-J. Wang, K.-H. Huang, Y.-J. Lee, W.-M. Chan and Y.-C. Chang, Anthocyanins from Hibiscus sabdariffa calyx attenuate in vitro, and in vivo melanoma cancer metastasis, J. Funct. Foods, 2018, 48, 614-631.

24 M. Tajaldini, F. Samadi, A. Khosravi, A. Ghasemnejad and J. Asadi, Protective and anticancer effects of orange peel extract and naringin in doxorubicin treated esophageal cancer stem cell xenograft tumor mouse model, Biomed. Pharmacother., 2020, 121, 109594.

25 J. Yan, Q. Wang, X. Zheng, H. Sun, Y. Zhou, D. Li, Y. Lin and $\mathrm{X}$. Wang, Luteolin enhances TNF-related apoptosisinducing ligand's anticancer activity in a lung cancer xenograft mouse model, Biochem. Biophys. Res. Commun., 2012, 417, 842-846.

26 A. K. Das, V. Rajkumar, P. K. Nanda, P. Chauhan, S. R. Pradhan and S. Biswas, Antioxidant efficacy of litchi (Litchi chinensis, Sonn.) pericarp extract in sheep meat nuggets, Antioxidants, 2016, 5, 1-10.

27 B. Sordini, G. Veneziani, M. Servili, S. Esposto, R. Selvaggini, A. Lorefice and A. Taticchi, A quanti-qualitat- ive study of a phenolic extract as a natural antioxidant in the frying processes, Food Chem., 2019, 279, 426-434.

28 C. Caleja, L. Barros, A. L. Antonio, M. Carocho, M. B. P. P. Oliveira and I. C. F. R. Ferreira, Fortification of yogurts with different antioxidant preservatives: A comparative study between natural and synthetic additives, Food Chem., 2016, 210, 262-268.

29 T. L. Swer, K. Chauhan, C. Mukhim, K. Bashir and A. Kumar, Application of anthocyanins extracted from Sohiong (Prunus nepalensis L.) in food processing, Lebensm.-Wiss. Technol., 2019, 114, 108360.

30 J. C. Baldin, E. C. Michelin, Y. J. Polizer, I. Rodrigues, S. H. S. Godoy, R. P. Fregonesi, M. A. Pires, L. T. Carvalho, C. S. Fávaro-Trindade, C. G. de Lima, A. M. Fernandes and M. A. Trindade, Microencapsulated jabuticaba (Myrciaria cauliflora) extract added to fresh sausage as natural dye with antioxidant and antimicrobial activity, Meat Sci., 2016, 118, 15-21.

31 A. Ribeiro, C. Caleja, L. Barros, C. Santos-Buelga, M. F. Barreiro and I. C. F. R. Ferreira, Rosemary extracts in functional foods: Extraction, chemical characterization and incorporation of free and microencapsulated forms in cottage cheese, Food Funct., 2016, 7, 2185-2196.

32 D. Pasrija, P. N. Ezhilarasi, D. Indrani and C. Anandharamakrishnan, Microencapsulation of green tea polyphenols and its effect on incorporated bread quality, Lebensm.-Wiss. Technol., 2015, 64, 289-296.

33 A. Rashidinejad, E. J. Birch, D. Sun-Waterhouse and D. W. Everett, Delivery of green tea catechin and epigallocatechin gallate in liposomes incorporated into low-fat hard cheese, Food Chem., 2014, 156, 176-183.

34 D. J. Cherubim, C. V. Martins, L. Fariña and R. A. Lucca, Polyphenols as natural antioxidants in cosmetics applications, J. Cosmet. Dermatol., 2020, 19, 33-37.

35 M. Kamma, W. C. Lin, S.-C. Lau, S. Chansakaow and P. Leelapornpisid, Anti-aging Cosmeceutical Product Containing of Nymphaea rubra Roxb. ex Andrews extract, Chiang Mai J. Sci., 2019, 46, 1143-1160.

36 S. Wang, P. Xia, S. Wang, J. Liang, Y. Sun, P. Yue and $\mathrm{X}$. Gao, Packaging films formulated with gelatin and anthocyanins nanocomplexes: physical properties, antioxidant activity and its application for olive oil protection, Food Hydrocolloids, 2019, 96, 617-624.

37 Y. Wang, H. Du, M. Xie, G. Ma, W. Yang, Q. Hu and F. Pei, Characterization of the physical properties and biological activity of chitosan films grafted with gallic acid and caffeic acid: A comparison study, Food Packag. Shelf Life, 2019, 22, 100401.

38 A. Cano, M. Andres, A. Chiralt and C. González-Martinez, Use of tannins to enhance the functional properties of protein based films, Food Hydrocolloids, 2020, 100, 105443.

39 M. Á. Bonet-Aracil, P. Díaz-García, E. Bou-Belda, N. Sebastiá, A. Montoro and R. Rodrigo, UV protection from cotton fabrics dyed with different tea extracts, Dyes Pigm., 2016, 134, 448-452. 
40 U. Złotek, U. Szymanowska, A. Jakubczyk, M. Sikora and M. Świeca, Effect of arachidonic and jasmonic acid elicitation on the content of phenolic compounds and antioxidant and anti-inflammatory properties of wheatgrass (Triticum aestivum, L.), Food Chem., 2019, 288, 256261.

41 J. Komaikul, T. Kitisripanya, K. Likhitwitayawuid, B. Sritularak, H. Tanaka and W. Putalun, Improvement of stilbenoid production by 2-hydroxypropyl- $\beta$-cyclodextrin in white mulberry (Morus alba L.) callus cultures, Nat. Prod. Res., 2019, 33, 2762-2769.

42 M. S. Iqbal, Z. Iqbal and M. I. Ansari, in Acta Agrobotanica, 2019, vol. 72.

43 M. Li, K. R. Kildegaard, Y. Chen, A. Rodriguez, I. Borodina and J. Nielsen, De novo production of resveratrol from glucose or ethanol by engineered Saccharomyces cerevisiae, Metab. Eng., 2015, 32, 1-11.

44 J. M. Camacho-Zaragoza, G. Hernández-Chávez, F. MorenoAvitia, R. Ramírez-Iñiguez, A. Martínez, F. Bolívar and G. Gosset, Engineering of a microbial coculture of Escherichia coli, strains for the biosynthesis of resveratrol, Microb. Cell Fact., 2016, 15, 163.

45 W. Zhang, H. Liu, X. Li, D. Liu, X.-T. Dong, F.-F. Li, E.-X. Wang, B.-Z. Li and Y.-J. Yuan, Production of naringenin from D-xylose with co-culture of $E$. coli and S. cerevisiae, Eng. Life Sci., 2017, 17, 1021-1029.

46 J. M. Mar, L. S. da Silva, A. C. Lira, V. F. Kinupp, M. I. Yoshida, W. P. Moreira, E. Bruginski, F. R. Campos, M. B. Machado, T. P. de Souza, P. H. Campelo, J. de Araújo Bezerra and E. A. Sanches, Bioactive compounds-rich powders: Influence of different carriers and drying techniques on the chemical stability of the Hibiscus acetosella, extract, Powder Technol., 2020, 360, 383-391.

47 V. B. de Souza, M. Thomazini, I. E. Chaves, R. FerroFurtado and C. S. Favaro-Trindade, Microencapsulation by complex coacervation as a tool to protect bioactive compounds and to reduce astringency and strong flavor of vegetable extracts, Food Hydrocolloids, 2020, 98, 105244.

48 G. Ozkan, P. Franco, I. De Marco, J. Xiao and E. Capanoglu, A review of microencapsulation methods for food antioxidants: Principles, advantages, drawbacks and applications, Food Chem., 2019, 272, 494-506.

49 Z. Fang and B. Bhandari, Encapsulation of polyphenols - a review, Trends Food Sci. Technol., 2010, 21, 510-523.

50 P. Labuschagne, Impact of wall material physicochemical characteristics on the stability of encapsulated phytochemicals: A review, Food Res. Int., 2018, 107, 227-247.

51 E. M. F. Lima, M. C. M. Madalão, W. C. dos Santos, P. C. Bernardes, S. H. Saraiva and P. I. Silva, Spray-dried microcapsules of anthocyanin-rich extracts from Euterpe edulis, M. as an alternative for maintaining color and bioactive compounds in dairy beverages, J. Food Sci. Technol., 2019, 56, 4147-4157.

52 S. Gomes, P. V. Finotelli, V. F. Sardela, H. M. G. Pereira, R. E. Santelli, A. S. Freire and A. G. Torres, Microencapsulated Brazil nut (Bertholletia excelsa) cake extract powder as an added-value functional food ingredient, Lebensm.-Wiss. Technol., 2019, 116, 108495.

53 D. S. Pillai, P. Prabhasankar, B. S. Jena and C. Anandharamakrishnan, Microencapsulation of Garcinia cowa fruit extract and effect of its use on pasta process and quality, Int. J. Food Prop., 2012, 15, 590-604.

54 P. Moser, V. R. N. Telis, N. de Andrade Neves, E. GarcíaRomero, S. Gómez-Alonso and I. Hermosín-Gutiérrez, Storage stability of phenolic compounds in powdered BRS Violeta grape juice microencapsulated with protein and maltodextrin blends, Food Chem., 2017, 214, 308-318.

55 C. L. de Dicastillo, C. Piña, L. Garrido, C. Arancibia and M. J. Galotto, Enhancing thermal stability and bioaccesibility of açaí fruit polyphenols through electrohydrodynamic encapsulation into zein electrosprayed particles, Antioxidants, 2019, 8, 464.

56 Y. Aguilera, L. Mojica, M. Rebollo-Hernanz, M. Berhow, E. G. de Mejía and M. A. Martín-Cabrejas, Black bean coats: New source of anthocyanins stabilized by $\beta$-cyclodextrin copigmentation in a sport beverage, Food Chem., 2016, 212, 561-570.

57 N. Kanha, S. Surawang, P. Pitchakarn, J. M. Regenstein and T. Laokuldilok, Copigmentation of cyanidin 3-O-glucoside with phenolics: Thermodynamic data and thermal stability, Food Biosci., 2019, 30, 100419.

58 O. O. Olatunde, S. Benjakul, K. Vongkamjan and T. Amnuaikit, Liposomal Encapsulated Ethanolic Coconut Husk Extract: Antioxidant and Antibacterial Properties, J. Food Sci., 2019, 84, 3664-3673.

59 Z. Ahmadian, R. Niazmand and A. Pourfarzad, Microencapsulation of Saffron Petal Phenolic Extract: Their characterization, in vitro gastrointestinal digestion, and storage stability, J. Food Sci., 2019, 84, 2745-2757.

60 M. Mansour, M. Salah and X. Xu, Effect of microencapsulation using soy protein isolate and gum arabic as wall material on red raspberry anthocyanin stability, characterization, and simulated gastrointestinal conditions, Ultrason. Sonochem., 2020, 63, 104927.

61 R. Zhang, L. Zhou, J. Li, H. Oliveira, N. Yang, W. Jin, Z. Zhu, S. Li and J. He, Microencapsulation of anthocyanins extracted from grape skin by emulsification/internal gelation followed by spray/freeze-drying techniques: Characterization, stability and bioaccessibility, Lebensm.Wiss. Technol., 2020, 123, 109097.

62 A. Rashidinejad, E. J. Birch, D. Sun-Waterhouse and D. W. Everett, Effect of liposomal encapsulation on the recovery and antioxidant properties of green tea catechins incorporated into a hard low-fat cheese following in vitro, simulated gastrointestinal digestion, Food Bioprod. Process., 2016, 100, 238-245.

63 F. Hasibi, A. Nasirpour, J. Varshosaz, P. García-Manrique, M. C. Blanco-López, G. Gutiérrez and M. Matos, Formulation and characterization of taxifolin-loaded lipid nanovesicles (liposomes, niosomes, and transfersomes) for beverage fortification, Eur. J. Lipid Sci. Technol., 2020, 122, 1900105. 
64 M. Gültekin-Özgüven, A. Karadağ, Ş. Duman, B. Özkal and B. Özçelik, Fortification of dark chocolate with spray dried black mulberry (Morus nigra) waste extract encapsulated in chitosan-coated liposomes and bioaccessability studies, Food Chem., 2016, 201, 205-212.

65 A. F. Esfanjani, E. Assadpour and S. M. Jafari, Improving the bioavailability of phenolic compounds by loading them within lipid-based nanocarriers, Trends Food Sci. Technol., 2018, 76, 56-66.

66 C.-F. Luo, M. Yuan, M.-S. Chen, S.-M. Liu, L. Zhu, B.-Y. Huang, X.-W. Liu and W. Xiong, Pharmacokinetics, tissue distribution and relative bioavailability of puerarin solid lipid nanoparticles following oral administration, Int. J. Pharm., 2011, 410, 138-144.

67 D. Pandita, S. Kumar, N. Poonia and V. Lather, Solid lipid nanoparticles enhance oral bioavailability of resveratrol, a natural polyphenol, Food Res. Int., 2014, 62, 11651174.

68 C. Del Bo', P. Riso, A. Brambilla, C. Gardana, A. Rizzolo, P. Simonetti, G. Bertolo, D. Klimis-Zacas and M. Porrini, Blanching Improves Anthocyanin Absorption from Highbush Blueberry (Vaccinium corymbosum L.) Purée in Healthy Human Volunteers: A Pilot Study, J. Agric. Food Chem., 2012, 60, 9298-9304.

69 K. Balagangadharan, R. Trivedi, M. Vairamani and N. Selvamurugan, Sinapic acid-loaded chitosan nanoparticles in polycaprolactone electrospun fibers for bone regeneration in vitro and in vivo, Carbohydr. Polym., 2019, 216, 1-16.

70 M.-J. Zhang, H. Su, J.-Y. Yan, N. Li, Z.-Y. Song, H.-J. Wang, L.-G. Huo, F. Wang, W.-S. Ji, X.-J. Qu and M.-H. Qu, Chemopreventive effect of Myricetin, a natural occurring compound, on colonic chronic inflammation and inflammation-driven tumorigenesis in mice, Biomed. Pharmacother., 2018, 97, 1131-1137.

71 Y. Ting, Y.-S. Chiou, M.-H. Pan, C.-T. Ho and Q. Huang, In vitro and in vivo anti-cancer activity of tangeretin against colorectal cancer was enhanced by emulsion-based delivery system, J. Funct. Foods, 2015, 15, 264-273.

72 S. Yang, H. Wang, Y. Yang, R. Wang, Y. Wang, C. Wu and $\mathrm{G}$. Du, Baicalein administered in the subacute phase ameliorates ischemia-reperfusion-induced brain injury by reducing neuroinflammation and neuronal damage, Biomed. Pharmacother., 2019, 117, 109102.

73 X. Qian, Z.-R. Wang, J.-J. Zheng, J.-Q. Ding, J.-G. Zhong, T.-Y. Zhang, W. Li and M. Zhang, Baicalein improves cognitive deficits and hippocampus impairments in temporal lobe epilepsy rats, Brain Res., 2019, 1714, 111-118.

74 F. N. Ekinci Akdemir, İ. Gülçin, B. Karagöz, R. Soslu and S. H. Alwasel, A comparative study on the antioxidant effects of hesperidin and ellagic acid against skeletal muscle ischemia/reperfusion injury, J. Enzyme Inhib. Med. Chem., 2016, 31, 114-118.

75 Y. Zu, W. Wu, X. Zhao, Y. Li, C. Zhong and Y. Zhang, The high water solubility of inclusion complex of taxifolin- $\gamma$-CD prepared and characterized by the emulsion solvent evapor- ation and the freeze drying combination method, Int. J. Pharm., 2014, 477, 148-158.

76 M. Zych, W. Wojnar, S. Dudek and I. Kaczmarczyk-Sedlak, Rosmarinic and sinapic acids may increase the content of reduced glutathione in the lenses of estrogen-deficient rats, Nutrients, 2019, 11, 803.

77 H. Lee, W. Shim, C. E. Kim, S. Y. Choi, H. Lee and J. Yang, Therapeutic efficacy of nanocomplex of poly(ethylene glycol) and catechin for dry eye disease in a mouse model, Invest. Ophthalmol. Visual Sci., 2017, 58, 1682-1691.

78 C. M. Borges, A. Papadimitriou, D. A. Duarte, J. M. Lopes De Faria and J. B. Lopes De Faria, The use of green tea polyphenols for treating residual albuminuria in diabetic nephropathy: A double-blind randomised clinical trial, Sci. Rep., 2016, 6, 1-9.

79 N. Rezvan, A. Moini, L. Janani, K. Mohammad, A. Saedisomeolia, M. Nourbakhsh, S. Gorgani-Firuzjaee, M. Mazaherioun and M. Hosseinzadeh-Attar, Effects of quercetin on adiponectin-mediated insulin sensitivity in polycystic ovary syndrome: a randomized placebo-controlled double-blind clinical trial, Horm. Metab. Res., 2016, 49, 115-121.

80 C. P. Li, G. Z. Qiu, B. Liu, J. L. Chen and H. T. Fu, Neuroprotective effect of lignans extracted from Eucommia ulmoides Oliv. on glaucoma-related neurodegeneration, Neurol. Sci., 2016, 37, 755-762.

81 E. Skrzypczak-Pietraszek, A. Urbańska, P. Żmudzki and J. Pietraszek, Elicitation with methyl jasmonate combined with cultivation in the Plantform ${ }^{\mathrm{TM}}$ temporary immersion bioreactor highly increases the accumulation of selected centellosides and phenolics in Centella asiatica (L.) Urban shoot culture, Eng. Life Sci., 2019, 19, 931-943.

82 G. Gutiérrez-Gamboa, T. Garde-Cerdán, L. MartínezLapuente, B. S. Costa, P. Rubio-Bretón and E. P. PérezÁlvarez, Phenolic composition of Tempranillo Blanco (Vitis vinifera, L.) grapes and wines after biostimulation via a foliar seaweed application, J. Sci. Food Agric., 2020, 100, 825-835.

83 R. K. Singh, V. Martins, B. Soares, I. Castro and V. Falco, Chitosan application in vineyards (Vitis vinifera L. cv. Tinto Cão) induces accumulation of anthocyanins and other phenolics in berries, mediated by modifications in the transcription of Secondary Metabolism Genes, Int. J. Mol. Sci., 2020, 21, 306.

84 L. Pistelli, M. Tonelli, E. Pellegrini, L. Cotrozzi, C. Pucciariello, A. Trivellini, G. Lorenzini and C. Nali, Accumulation of rosmarinic acid and behaviour of ROS processing systems in Melissa officinalis, L. under heat stress, Ind. Crops Prod., 2019, 138, 111469.

85 J. Wu, G. Du, J. Chen and J. Zhou, Enhancing flavonoid production by systematically tuning the central metabolic pathways based on a CRISPR interference system in Escherichia coli, Sci. Rep., 2015, 5, 13477.

86 J. A. Jones, V. R. Vernacchio, A. L. Sinkoe, S. M. Collins, M. H. A. Ibrahim, D. M. Lachance, J. Hahn and 
M. A. G. Koffas, Experimental and computational optimization of an Escherichia coli, co-culture for the efficient production of flavonoids, Metab. Eng., 2016, 35, 55-63.

87 A. Rodriguez, T. Strucko, S. G. Stahlhut, M. Kristensen, D. K. Svenssen, J. Forster, J. Nielsen and I. Borodina, Metabolic engineering of yeast for fermentative production of flavonoids, Bioresour. Technol., 2017, 245, 1645-1654.

88 S. Ho, Y. Y. Thoo, D. J. Young and L. F. Siow, Inclusion complexation of catechin by $\beta$-cyclodextrins: Characterization and storage stability, Lebensm.-Wiss. Technol., 2017, 86, 555-565.
89 A. Fernandes, M. A. A. Rocha, L. M. N. B. F. Santos, J. Brás, J. Oliveira, N. Mateus and V. Freitas, Blackberry anthocyanins: $\beta$-Cyclodextrin fortification for thermal and gastrointestinal stabilization, Food Chem., 2018, 245, 426-431.

90 V. Sanchez, R. Baeza and J. Chirife, Comparison of monomeric anthocyanins and colour stability of fresh, concentrate and freeze-dried encapsulated cherry juice stored at $38^{\circ}$ C, J. Berry Res., 2015, 5, 243-251.

91 D. Dag and M. H. Oztop, Formation and characterization of green tea extract loaded liposome, J. Food Sci., 2017, 82, 463-470. 